\title{
"A Comparative Study to Assess the Effectiveness of Structured Teaching Programme on Knowledge of Chikungunya among Young Adults"
}

\author{
Rajkumari Gunisana Devi ${ }^{1}$ Balbir Yadav ${ }^{2}$ \\ ${ }^{1}$ Professor, Sri Guru Harkrishan sahib College of Nursing, Sohana, Mohali Punjab \\ ${ }^{2}$ Professor cum Vice-Principal, Sri Guru Harkrishan sahib College of Nursing, Sohana, Mohali Punjab
}

Corresponding E-Mail : balbyadav@gmail.com

\begin{abstract}
Introduction: Health is the precious possession of all human being as it is an asset for an individual and community as well. The communicable disease is transmitted through some source such as person to person, animal to animal, from the environment(through air, soil, dust, food, water etc.) and from animal to person, which also involves a vector. Vector may be mechanical or biological.

Method \& Material: The current study was aim to assess the Effectiveness of Structured Teaching Programme on Knowledge of Chikungunya among Young Adults. The research approach adopted in the present study was evaluative approach, and research design was one group pre test and post test design for both urban and rural areas which belongs to pre- experimental design. Purposive Non random sampling technique was used to select the area as well as the sample. The sample size was of 60 young adults (30 from Zaheerabad urban area urban area and 30 from Chandrabanda rural areas) of Raichur. Data were collected by using structured interview schedule and structured teaching programme was intervened, again after a gap of seven days post test was conducted with the same tool.

Result: Result showed that In urban area, the pre test mean score was $11.50(\mathrm{~S} . \mathrm{D}=1.90)$ and in post test it was 19.26 (S.D =1.94). Whereas in rural area, the pre test mean score was $11.26(\mathrm{~S} . \mathrm{D}=1.98)$ and in post test it was 19.36 (S.D =2.22) which indicated an improvement in the knowledge level of the respondents after structured teaching programme.
\end{abstract}

Key words: Structured Teaching Programme, Knowledge, Chikungunya

\section{INTRODUCTION}

Health is the precious possession of all human being as it is an asset for an individual and community as well. It is a basic fundamental right of each individual, to maintain a level of health that will promote them to work productively and participate actively in the social life of their community. A person is said to be healthy when he or she is completely fit with physical, mental, spiritual and well adjusted with their environment and also if there is no complaints or absence of any discomfort

There are various factors which affects man's health. A man is prone to get diseases through different mode of transmission such as water borne, air borne, vector borne and vehicle borne diseases. Among these, the vector borne disease are the one which are transmitted by insects from one person to another person thereby making the epidemic to be originated. Chikungunya is one of the vectors - borne disease caused by alpha virus which belongs to the family Togaviridae. An infected person cannot spread the infection directly to other persons. Aedes mosquitoes bite during the day and spread this infection

The incubation period of chikungunya virus ranges from 1-12 days, usually 3-7 days. The signs and symptoms of chikungunya infection are fever with $102.2^{\circ} \mathrm{F}$, maculopapular rash usually involving the limbs and trunk, arthralgia or arthritis affecting multiples joints which can be debilitating. There can also be headache, conjunctival infections and slight photophobia, sometimes nausea and vomiting. The viral diagnostic (culture, serological tests and polymerase chain reaction tests) can be used to confirm the chikungunya infection. 
Chloroquine $250 \mathrm{mg}$ /day and aspirin are used to treat arthritis lead by chikungunya infection. Ayurvedic treatment is also available and is effective and can cure its many symptoms. Ginger chutney, neem chutney, coriander leaves chutney are effective medicine, ganji has to be taken either with butter milk or milk; the joints can be massaged with pure camphor combined with coconut oil at least thrice each time for 2-3 minutes is necessary. The complications of the chikungunya infection includes meningitis, encephalitis etc

Prevention can be done by protecting individual themselves from bites of mosquitoes and it is possible by controlling proliferation of mosquitoes in stagnant water, properly covering all water tanks, people should wear long sleeves shirts and long pants, use of mosquito spray, repellents (coils, cream), chemical agents such as NNDB, DEET etc are used to kill Aedes mosquitoes.

Young adults are more energetic and the pillars of the society. will pay more attention and interest in learning new knowledge or ideas; they are good learner and can share the new information and teach to their family members and community people. The programme conducted will make them to know more about chikungunya virus and voluntarily they will participate actively in the prevention, control and management of chikungunya virus.

\section{METHODS}

The research approach adopted in the present study was evaluative approach, and research design was one group pre test and post test design for both urban and rural areas which belongs to preexperimental design. Purposive Non random sampling technique was used to select the area as well as the sample. The sample size was of 60 young adults $(30$ from Zaheerabad urban area urban area and 30 from Chandrabanda rural areas). The pilot study revealed the feasibility of the study. Reliability of the tool was determined by the test retest method. By using Karl Pearson's co- efficient of co relation method " $r$ " value is obtained. $\left[r^{1}=0.92\right.$ for Siyatalab Urban, $r^{1}=0.85$ for Yereegera Rural]. It shows that the tool was highly reliable for the final study. Data were collected by using structured interview schedule through multiple choice questions and structured teaching programme was intervened, again after a gap of seven days post test was conducted with the same tool. Analysis of the data was done by using descriptive statistics as mean, standard deviation and paired't' test and inferential statistics as Unpaired ' $t$ ' test and Chi- square test.
The analysis and interpretation of data have been organized and presented under the following section.

Table : 1 Frequency and Percentage Distribution of Levels of Knowledge of young adults regarding chikungunya of Urban and Rural area in Pre-Test and Post Test

\begin{tabular}{|l|c|c|c|c|c|c|c|c|}
\hline \multirow{2}{*}{$\begin{array}{l}\text { Levels of } \\
\text { Knowledge }\end{array}$} & \multicolumn{4}{|c|}{ Urban Area } & \multicolumn{4}{c|}{ Rural Area } \\
\cline { 2 - 9 } & \multicolumn{2}{|c|}{ Pre Test } & \multicolumn{2}{|c|}{ Post Test } & \multicolumn{2}{|c|}{ Pre Test } & \multicolumn{2}{c|}{ Post Test } \\
\cline { 2 - 9 } & Frequency & $\%$ & Frequency & $\%$ & Frequency & $\%$ & Frequency & $\%$ \\
\hline High Knowledge & 0 & 0 & 20 & 66.67 & 0 & 0 & 18 & 60 \\
\hline Average Knowledge & 9 & 30 & 10 & 33.33 & 8 & 26.67 & 12 & 40 \\
\hline Low Knowledge & 21 & 70 & 0 & 0 & 22 & 73.33 & 0 & 0 \\
\hline
\end{tabular}

Table No. 1 shows that In urban area, (70.00\%) of young adults had low knowledge followed by $(30.00 \%)$ had average knowledge. Whereas in post test $(66.67 \%)$ had high knowledge followed by $(33.33 \%)$ had average knowledge in pre test.

\section{RESULTS}

Majority of young adults had low knowledge $(73.33 \%)$ followed by average knowledge (26.67\%) in rural area, whereas in post test $(60.00 \%)$ had high knowledge followed by $(40.00 \%)$ average knowledge.

Table 2 Mean and Standard Deviation of pre test and post test knowledge scores of Urban area and Rural area

\begin{tabular}{|l|l|l|l|c|}
\hline $\begin{array}{l}\text { Knowledge of } \\
\text { Chikungunya }\end{array}$ & \multicolumn{2}{|c|}{ Pre Test } & \multicolumn{2}{c|}{ Post Test } \\
\hline & Mean & SD & Mean & SD \\
\hline Urban area & 11.50 & 1.90 & 19.26 & 1.94 \\
\hline Rural area & 11.26 & 1.98 & 19.36 & 2.22 \\
\hline
\end{tabular}

Table No. 2 Shows that In urban area, the pre test mean score was 11.50 (S.D =1.90) and in post test it was $19.26(\mathrm{~S} . \mathrm{D}=1.94)$. In rural area, the pre test mean score was $11.26(\mathrm{~S} . \mathrm{D}=1.98)$ and in post test it was 19.36 (S.D $=2.22$ ) which indicated an improvement in the knowledge level of the respondents after structured teaching programme.

Table - 3 Comparison of knowledge scores of young adults before and after Structured Teaching Programme of Urban area and Rural area.

\begin{tabular}{|l|l|l|l|l|}
\hline $\begin{array}{c}\text { Knowledge of } \\
\text { Chikungunya }\end{array}$ & $\begin{array}{c}\text { Mean } \\
\text { diff }\end{array}$ & $\begin{array}{c}\text { SD } \\
\text { Difference }\end{array}$ & $\begin{array}{c}\text { SE } \\
\text { differe }\end{array}$ & $\begin{array}{c}\text { Pairedt } \\
\text { test }\end{array}$ \\
\hline Urban area & -7.76 & 2.55 & 0.46 & -16.65 \\
\hline Rural area & -8.10 & 3.20 & 0.58 & -13.82 \\
\hline
\end{tabular}


Table No. 3 Shows that Urban area Mean difference of ( -7.76), S.D $=2.55$ of overall knowledge with paired ' $t$ ' value (-16.65) and Rural area Mean difference of ($8.10)$, S.D $=3.20$ of overall knowledge with paired't' value (-13.82). Thus it reveals that the mean post test knowledge scores were significantly higher than the mean pre test knowledge scores of young adults. It shows there is a significant difference between pre test and post test knowledge scores.

Table-4 Comparing the post knowledge scores of young adults between rural \& urban areas

\begin{tabular}{|l|l|l|l|l|c|}
\hline Urban & & Rural & & SE & Unpaired ' $t$ ' test \\
\cline { 1 - 5 } Mean & SD & Mean & SD & & \\
\cline { 1 - 4 } 19.27 & 1.95 & 19.37 & 2.22 & 0.53 & $0.19^{*}$ \\
\hline
\end{tabular}

Table No. 4 Shows that the mean $19.37($ S.D $=2.22)$ in rural area whereas mean $19.27($ S.D $=1.95)$ in urban area and the unpaired't' value is 0.19 . It means the post test knowledge scores of young adults of urban area are not differ from the post test knowledge scores of young adults of rural area. Hence the effect of structured teaching programme regarding chikungunya among young adults of urban area and rural area are the same.

Table-5 Association between socio demographic variables of young adults with their post test knowledge scores in urban area.

\begin{tabular}{|l|c|c|c|c|}
\hline Variables & $\begin{array}{c}\text { Calculated } \\
\Rightarrow^{2} \text { value }\end{array}$ & Association & $\begin{array}{c}\text { Degree of } \\
\text { freedom }\end{array}$ & $\begin{array}{c}\Rightarrow^{2} \text { Table value } \\
\text { at 5\% level of } \\
\text { significance }\end{array}$ \\
\hline Age & 1.07 & NS & 1 & 3.84 \\
\hline Education & 2.4 & NS & 1 & 3.84 \\
\hline Occupation & 0.067 & NS & 1 & 3.84 \\
\hline Family monthly income & 0.093 & NS & 1 & 3.84 \\
\hline Sources of information & 0.070 & NS & 1 & 3.84 \\
\hline
\end{tabular}

Note: NS denotes No Significant.

Table-6 Association between socio demographic variables of young adults with their post test knowledge scores in rural area.

\begin{tabular}{|l|c|c|c|c|}
\hline Variables & $\begin{array}{c}\text { Calculated } \Rightarrow \\
\text { value }\end{array}$ & Association & $\begin{array}{c}\text { Degree of } \\
\text { freedom }\end{array}$ & $\begin{array}{c}\Rightarrow \text { Table } \\
\text { value at } \\
\mathbf{5 \%} \text { level of } \\
\text { significance }\end{array}$ \\
\hline Age & 0.21 & NS & 1 & 3.84 \\
\hline Education & 0.36 & NS & 1 & 3.84 \\
\hline Occupation & 0.45 & NS & 1 & 3.84 \\
\hline Family monthly income & 1.43 & NS & 1 & 3.84 \\
\hline Sources of information & 0.36 & NS & 1 & 3.84 \\
\hline
\end{tabular}

Table No. 6 Shows that there is no significant relationship between age, education, occupation, family monthly income and sources of information regarding chikungunya with post test knowledge scores of young adults regarding chikungunya inUrban area and rural area.

\section{DISSCUSSION}

Healthy environment depends upon the healthy family. Healthy family again depends upon the individual. Every individual have the right of good health. As many micro organisms are around human, there is a need for everyone to make aware how to protect and how to prevent from occurrence of diseases.

- In urban area, the pre test mean score was 11.50 (S.D $=1.90)$ and in post test it was 19.26 (S.D $=1.94)$. Whereas in rural area, the pre test mean score was $11.26(\mathrm{~S} . \mathrm{D}=1.98)$ and in post test it was $19.36(\mathrm{~S} . \mathrm{D}=$ 2.22) which indicated an improvement in the knowledge level of the respondents after structured teaching programme.

- Paired't' value was computed to evaluate the structured teaching programme on chikungunya. The obtained value was $(-16.65)$ in urban area and (13.82) in rural area which was significant at 0.05 level indicating the effectiveness of the Structured Teaching Programme.

Unpaired't' test was used to compare the post test knowledge scores of rural young adults and urban young adults. The mean value was $19.37(\mathrm{~S} . \mathrm{D}=2.22)$ in rural area and $19.27(\mathrm{~S} . \mathrm{D}=1.95 \%)$ in urban area. This means that there was no difference in post test knowledge scores of young adults in rural and urban areas.

- The significant association was not found in both urban area and rurals area between the post test knowledge scores of young adults regarding chikungunya with age, education, occupation, family monthly income and source of information regarding chikungunya.

\section{CONCLUSION}

The conclusion of the study regarding knowledge of chikungunya in urban area, the pre test mean score was $11.50(\mathrm{~S} . \mathrm{D}=1.90)$ and in post test it was 19.26 (S.D =1.94). Whereas in rural area, the pre test mean score was 11.26 (S.D =1.98) and in post test it was 19.36 ( $\mathrm{S} . \mathrm{D}=2.22$ ) which indicated an improvement in the knowledge level of the respondents after structured teaching programme. Thus it reveals that the mean post 
test knowledge scores was significantly higher than the mean pre test knowledge scores of young adults regarding chikungunya Thus the research hypothesis was accepted. It shows that there is a significant difference between pre test and post test knowledge scores of young adults. Chi square result showed that there is no association was found in both urban area and rural area between the post test knowledge scores of young adults regarding chikungunya with age, education, occupation, family monthly income and source of information regarding chikungunya. Hence the research hypotheses related to above demographic variables has rejected.

\section{ACKNOWLEDGMENTS}

We would like to thank the investigator, and study participants of this study.

\section{REFERENCES}

1) Gualani. K.K, Textbook of Community Health Nursing $1^{\text {st }}$ edition, Kumar Publications, New Delhi :181-183

2) Park. K, Textbook of preventive and social medicine, $19^{\text {th }}$ edition, Jablapur(India); Banarsidas Publishers; $2007: 270$

3) Chastel. C: Chikungunya; recent spread to south Indian ocean Reunion Island, Bull academic National Medicine, 2006 vol 108:1027-35

4) History of Chikungunya fever, http://www. chikungunya.co.in

5) Ravi V. Re-emergence of Chikungunya virus in India. Indian J Med Microbial National institute of communicable Diseases 2006; 24: 83-84.

6) "Five lakhs with Chikungunya in state", New Indian Express, Bangalore, July $26^{\text {th }} 2006$.

7) National Vector Borne Disease Control Programme : Director General of Health Services (October 15 $\left.{ }^{\text {th }}\right)$ : cited (December 10 ${ }^{\text {th }} 2007$ ) available from URL

http://www.namp.gov.in/Chikun-Status.html

8) Status and Report on Dengue and Chikungunya as on 12 December 2006. National vector borne diseases control programme, Delhi 2006, available from http//namp.@gov.in (accessed on Dec 2006)

9) Sandhijwara.P.T, Sharma, A Report on Chikungunya out break in India, 2005,

http://www.google.com.
10) Dr. Padakula, Vasudeva Reddy, Recent Outbreak of Chikungunya, Nightingale Nursing Times, Vol. 3, Issue 4, 2007: 33,67.

11) National Vector Borne Disease Control Programme: Director General of Health Services (October 15 $5^{\text {th }}$ ): cited (December $10^{\text {th }} 2007$ ) available from URL http://www.namp.gov.in/Chikun-Status.html

12) Negoi. DK, Mitra.K. "Serosurvey of chikungunya antibody in calcutta metropolis' Dept of virology, school of tropical medicine, Calcutta, India, journal of community diseases, 1999 Mar ; 27 (1) : 19-22 Available on URL: www.pubmed.com PMID 7636147. 